\title{
Intellectual property rights related to the genetically modified glyphosate tolerant soybeans in Brazil
}

\author{
ROBERTA L. RODRIGUES ${ }^{1}$, CELSO L.S. LAGE ${ }^{2}$ and ALEXANDRE G. VASCONCELLOS ${ }^{3}$ \\ ${ }^{1}$ INPI - Diretoria de Patentes, Rua Mayrink Veiga, 9, $21^{\circ}$ andar, Centro, 20090-910 Rio de Janeiro, RJ, Brasil \\ ${ }^{2}$ INPI - Academia da Propriedade Industrial, Praça Mauá, 7, 1012, Centro, 20081-240 Rio de Janeiro, RJ, Brasil \\ ${ }^{3}$ INPI - CEDIN, Praça Mauá, 7, 709, Centro, 20081-240 Rio de Janeiro, RJ, Brasil
}

Manuscript received on October 19, 2009; accepted for publication on January 3, 2011

\begin{abstract}
The present work analyzes the different modalities of protection of the intellectual creations in the biotechnology agricultural field. Regarding the Brazilian legislations related to the theme (the Industrial Property Law - no. 9.279/96 and the Plant Variety Protection Law - no. 9.456/97), and based in the international treaties signed by Brazil, the present work points to the inclusions of each of them, as well as to their interfaces using as reference the case study of glyphosate tolerant genetically modified soybean. For this case study, Monsanto's pipelines patents were searched and used to analyze the limits of patent protection in respect to others related to the Intellectual Property (IP) laws. Thus, it was possible to elucidate the complex scenario of the Intellectual Property of the glyphosate tolerant soybeans, since for the farmer it is hard to correlate the royalties payment with the IP enterprise's rights.
\end{abstract}

Key words: biotechnology, GMO, intellectual property, patent, pipeline, soybean.

\section{INTRODUCTION}

The Brazilian Ministry of Agriculture and Supply points that the US, followed by Brazil and Argentina, were responsible for $81 \%$ of the world soybean production in 2005 (Ministério da Agricultura 2008b). In addition, in the previous year, the soybean was the second major Brazilian exportation product (Ministério da Agricultura 2008a, Análise 2007).

The genetically modified (GM) crop has provided a lot of advantages for farmers since its creation in the mid-1990s, like insect resistant or herbicide tolerant plants, and, for this reason, the planted area with transgenics has raised its value (James 2005, Lawrence 2008). The GM crops have increased dramatically; in 2005 they had an annual growth of $11 \%$. During the period of 1996 to 2005, herbicide tolerance had con-

Correspondence to: Roberta Lopes Rodrigues

E-mail: robertalopesrodrigues@yahoo.com.br sistenly been the dominant trait, followed by insect resistance (Bacillus thurigiensis or Bt resistance), and virus resistance or other traits, respectively, according to James (2005).

In 2005, soybean biotech crops occupied $60 \%$ of global biotech area, with the US, Argentina, Brazil, Canada and China being the principal adopters of this technology (James 2005). In the number of new hectars planted with transgenic crops, Brazil surpassed the US in 2007 and planted $28 \%$ of all new crops versus the $25 \%$ of the US (Lawrence 2008).

In Brazil, one of the most used herbicide tolerant crops is the glyphosate resistant soybeans. James (2005) projected that $44 \%$ of all soybean planted in Brazil in 2005/2006 was glyphosate resistant soybean. Glyphosate is a nonselective herbicide that, when used, does not distinguish between weeds or plants, and acts by inhibiting an enzyme called 5-enolpyruvylshikimate-3phosphate synthase (EPSPS), which catalyzes the cre- 
ation of three essential aromatic amino acids (tyrosine, phenylalanine and tryptophan) in plants. However, glyphosate resistant plants can survive in a concentration of glyphosate, which usually kills non - genetically modified plants. The farmer can apply such herbicide on genetically modified plants during their post-emergent period, and the plants will continue making the amino acids derived, as usual. The glyphosate herbicide is known by different commercial names, but the Rondup ready ${ }^{\circledR}$, made by Monsanto, is the most famous one. The glyphosate resistant soybean is also commonly known as Roundup ready ${ }^{\circledR}$ soybeans or $\mathrm{RR}^{\circledR}$ soybeans, and all technologies that confer tolerance to the glyphosate treated in this work are called $\mathrm{RR}^{\circledR}$ technologies.

In Brazil, the Industrial Property Law - IP Law no. 9.279/96 (Brasil 1996) and Plant Variety Protection Law - PVP Law 9.456/97 (Brasil 1997) were promulgated in the mid-1990's. These laws represent the Brazilian consonance with the international TRIPS ${ }^{1}$ agreement, which intended to harmonize the national Intellectual Property Laws among the Members States in order to establish the minimum standards of Intellectual Property protection.

The TRIPS agreement sets out the patent protection for all fields of technology, including genetically modified microrganisms and non-biological or microbiological process. Plants and animals are matters that can be protected by patents or sui generis protection system (WTO 2008). According to this ordainment, Brazil promulgated an Industrial Property Law (Law no. 9.279/96) that establishes the protection by patents of transgenic microrganisms and other processes that are not naturally biological, and a Plant Variety Protection Law (Law 9.456/97) to protect plant varieties, as the sui generis system. Thus, according to Brazillian Industrial Property Law in force, the only organism protected by patent is the transgenic microrganism.

Some studies have been carried out on the economic impacts of $R R^{\circledR}$ soybeans on the Brazilian agriculture (Pessanha et al. 2006, de Carvalho et al. 2005), while other works led with the confused diffusion process of $\mathrm{RR}^{\circledR}$ soybeans in Argentina (Cohen and Morgan 2008).

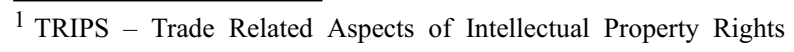
(TRIPS 1994).
In Argentina, the $\mathrm{RR}^{\circledR}$ technologies were not patentprotected, and the farms can legally "save seeds"2. However, their soy meal's exportation has continually been contested in European Courts (Quaim and Traxler 2005, Varela and Bisang 2006).

Regarding the innovation caused by $\mathrm{RR}^{\circledR}$ soybeans to the Brazilian agriculture and the fact that one of the basic indicators of Science and Technology directly relevant to measure the innovation is the patent statistics (OECD/Eurostat 1997), this study considers the Intellectual Property and the relation between the Intellectual Property Rights and the technological development as an essential tool to disclose the $\mathrm{RR}^{\circledR}$ technologies. Vasconcellos et al. (2005) had already used patents ${ }^{3}$ in order to understand the dynamics of the phytoterapic products patented in Brazil during the 90's. Like other studies that used patent searches to understand some aspects of a determined field, the present work adds technical and legal subjects to the debate by using, respectively, some glyphosate tolerance technologies and the Intellectual Property laws related to them. To explain these two points, this work intends to limit the extension of some of the claims' pipeline patents that confer the glyphosate tolerance to the $\mathrm{RR}^{\circledR}$ soybeans, under the point of view of the Brazilian Industrial Property Law, and to define the protection limits of the Plant Variety Protection Law associated to glyphosate tolerant soybeans in each step of the GM grain production chain. From these data, it will be possible to correlate clearly, through the grain chain production, each object of the chain with its protection correspondent Law.

In order to correlate which technology protected by the pipeline patents are indeed inside each $R^{\circledR}{ }^{\circledR}$ soybeans protected by the Plant Variety Protection Law, their abstracts ${ }^{4}$ published by the Union Oficial Diary were analyzed. In this way, a more detailed comparison will be possible between the $\mathrm{RR}^{\circledR}$ soybean varieties protected by the Plant Variety Protection Law and the scope

\footnotetext{
2 "Save seeds" is an usual term that refers to the act of keeping seeds obtained by the seeds previously sowed for use them in future yields instead of selling them as grains in the market.

${ }^{3}$ A legal right of property over an invention granted by national patent offices.

${ }^{4}$ An abstract of a variety allows the identification of the object of the application, according to the Article 14 (XII) of the Law 9.456/97.
} 
of protection of the pipeline patents that protects the glyphosate tolerance technologies or $\mathrm{RR}^{\circledR}$ technologies.

\section{DATA AND METHODS}

Pipeline Database And Delimitation of the

TeChnical EXTENSION OF The Claims'

Pipeline PATENTs

To obtain patents related to the glyphosate resistance technology, a search for the applicant "Monsanto" was done at INPI public database website (http:// www.inpi.gov.br) in June, 2007. For this work, fifteen patents were selected and only the patents filed as special protection mechanisms, regularly known as pipeline patents, were worked on. The selected pipeline patents were: PI 1100007-4, PI 1101067-3, PI 1101045-2, PI 1101070-3, PI 1100008-2, PI 1100006-6, PI 1101046-0, PI1 101048-7, PI 1101047-9, PI 1101063-0, PI 11010690 , PI 1100009-0, PI 1100464-9, PI 1101062-2 and PI 1100005-8. However, to validate this search, another search using an INPI's work (2001) was done, which confirmed the total number of the previous search.

After this, an analysis of these selected pipeline patents revealed that some of them are not related to this work and, for this reason, were discarded. The application documents that were denied by INPI were not considered either.

The eight pipeline patents chosen for this study were divided into two main groups (I and II) according to the matter claimed. Group $\mathrm{I}^{5}$ comprises pipeline patents that claim protection for the subject matter that can be used to obtain any transgenic plants, besides the $\mathrm{RR}^{\circledR}$ soybeans. Group $\mathrm{II}^{6}$ comprises patents that claim protection for the matter that can be used to obtain only $\mathrm{RR}^{\circledR}$ transgenic plants.

According to Article 41 of Law no. 9.279/96, the privilege is given on the basis of the scope of the claims. In order to delimit the technical extension of the exclusivity, the scope of the granted patents related to the glyphosate resistance technology was considered. The

\footnotetext{
5 The pipeline patents from group I: PI 1101048-7, PI 1101047-9, PI $1101063-0$, PI $1101069-0$, PI 1101067-3, PI $1101045-2$ and PI 1101070-3.

6 The pipeline patents from group II: PI 1100007-4, PI 1100008-2, PI 1100006-6 and PI 1101046-0.
}

analysis of the pipeline's claims from groups I and II was drawn on the scope of protection of two main categories of claims: the product (i.e., recombinant expression cassette, vector and transgenic microrganism) and the method (i.e., process to obtain a transgenic plant).

\section{Amino Acid Sequences Comparison Among THE PiPEline PATENTS From Group II (PI 110007-4 AND PI 110008-2) AT BLAST PROGRAM AND CLUSTAL PROGRAM}

The comparison of the mutated EPSPS amino acid sequences claimed in the pipeline PI 1100007-4, with those claimed in the PI 1100008-2 was made in order to find the identity of both sequences. The tool used was the Blast Two Sequences of the Blast Program (available at: http://www.ncbi.nlm.nih.gov/blast/bl2seq/ wblast2.cgi). Through this tool it is possible to reveal the degree of similarity among amino acids occupying a particular position in the sequence as a rough measure of how conserved a particular region is among the said sequences. The only amino acid sequence described in PI 1100007-4 (from Petunia EPSP cDNA) was aligned by the Blast Two Sequence with the amino acid sequences numbers 2, 4, 6, 9, 42 and 44 (respectively from Agrobacterium sp., Achromobacter sp, Pseudomonas sp., a synthetic CP4 Class II EPSPS protein sequence, Bacillus subtili and Staphylococcus aureus) described in the PI 110008-2.

As the domain protein sequences number 37, 38, 39 and 40 (PI 1100008-2) are too short, they have only four or five amino acids and were compared to sequences of the PI 1100007-4 and PI 1100008-2 in a multiple alignment in the CLUSTAL avaiable at: http:// www.ebi.ac.uk/clustalw/. This kind of alignment provides more accurate results than the double alignment (Santos Filho and Alencastro 2003).

INTERFACE ANALYSIS BETWEEN THE RR ${ }^{\circledR}$ SOYBEANS AND THEIR RELATED LEGISLATIONS

For the interface analysis between the GM organisms and their related legislations, a documental search was made with the laws that lead direct or indirectly to the glyphosate tolerant transgenic soybeans intellectual protection. These laws are: Industrial Property Law - Law 
no. $9.279 / 96$, in force to pipeline patents since May $14^{\text {th }}$, 1996, and the Plant Variety Protection Law - Law no. 9.456/97, in force since April 25 $5^{\text {th }}, 1997$.

\section{$\mathrm{RR}^{\circledR}$ SOYBEAN VARIETIES’ ABstracts}

In order to obtain the $\mathrm{RR}^{\circledR}$ varieties' abstracts protected by the Plant Variety Protection Law, no. 9.456/97, a search in the Brazilian Ministry of Agriculture and Supply was done on May $27^{\text {th }}, 2008$, to obtain the name of the $\mathrm{RR}^{\circledR}$ varieties protected.

The National Plant Varieties Protection Services (SNPC) gently granted the abstracts published by the Union Oficial Diary of the $\mathrm{RR}^{\circledR}$ varieties previously selected. In these public extracts, the following information about the varieties is available: the designation of the variety, the applicant's name, the applicant's home country, the novelty, the distinctness, the homogeneity and the stability characteristics. For the distinctness, the applicants indicate the gliphosate tolerance and other diferentiated characteristics related to the nearest variety, for example, height, intensity of leaf color, nematoid tolerance or seeds weight.

For the soybean descriptors, the Brazilian Ministry of Agriculture and Supply's form supplies examples of the minimum number of characteristics required by the UPOV. However, they do not include the specific genetic information inside a genetically modified variety as one of these minimum descriptors. For the comparison with the nearest variety, this form suggests that, if any important characteristic is not present in the list of descriptors, the applicant may indicate it and explain the differences among them.

\section{RESULTS AND DISCUSSION}

Pipeline Database and Delimitation of the Technical Extension of the Claims' Pipelines

To clearly understand the protection extension of the Monsanto's pipeline patents, the eight patents selected were divided into two groups. Table I represents the main differences between the subject matters covered by the claims of the pipeline patents of groups I and II.

In Table I it is possible to elucidate that pipeline patents from group 1 represent documents that describe technologies that are not exclusively found in the $\mathrm{RR}^{\circledR}$ technologies, but can also be in the $\mathrm{RR}^{\circledR}$ soybeans be- cause they envolve DNA recombinant technology in general. The pipeline patents from group II comprise patents that describe technologies that are directly related to $\mathrm{RR}^{\circledR}$ technologies and, consequently, to the $\mathrm{RR}^{\circledR}$ soybeans.

Although most of these pipeline patents had already expired, some of them are still in force or are tramiting in the Brazilian Court by Monsanto for increasing their terms of protection. This means that some patents may have their expiration date extended. Considering the fact that the expiration date limits the period of exclusive patent exploitation by the title's patents, this indicates that changes in the terms of protection of these pipelines will consequently change the period that the owner can charge royalties from thirds for using them.

\section{Amino Acid Sequences Comparison Among the Pipeline Patents From Group II (PI 110007-4 \\ AND PI 110008-2) AT BLAST PROgRAM AND \\ CLUSTAL PROGRAM}

The identity between the mutated EPSPS amino acid sequences of the PI 1100007-4 and the mutated Class II EPSPS amino acid sequences from PI 1100008-2 in their respective recombinant expression cassette showed that they have an identity of $30-35 \%$ in a low e-value. This low identity between the EPSPS amino acid sequences in the PI 1100007-4 and in the PI 1100008-2 demonstrates that they are extremelly different.

The CLUSTAL alignment analysis confirmed the BLAST results because it also revealed that all the sequences, including the domain sequences of the PI $1100008-2$, have regions that are poorly conserved structurally.

InTERfaCe ANALYSis BetweEn the RR ${ }^{\circledR}$ SOYBEANS AND THEIR RELATED LEGISLATIONS: THE INDUSTRIAL Property LaW (LAW No. 9.279/96) AND THE Pipeline Patents

When the legislator set up the pipeline protection mechanism, it was conditioned by some specific transitory provisions of the Industrial Property Law (IP Law), Articles $229^{7}, 230$ and 231.

\footnotetext{
${ }^{7}$ Although the Articles 229 and 231 of the Law 9.279/96 also regulate the transitory provisions known as pipeline, the patents of this work
} 
TABLE I

The scope of protection of the claims' pipeline patents of groups I and II, the pipeline patents and their expiration dates.

\begin{tabular}{|c|c|c|c|}
\hline Group & $\begin{array}{l}\text { Subject matters covered } \\
\text { by the claims }\end{array}$ & $\begin{array}{l}\text { Pipeline } \\
\text { patents }\end{array}$ & $\begin{array}{l}\text { Expiration } \\
\text { dates }\end{array}$ \\
\hline I & $\begin{array}{l}\text { - recombinant expression cassette, } \\
\text { including, but not exclusively, } \\
\text { sequences for glyphosate tolerance; } \\
\text { - vector that contains this } \\
\text { recombinant expression cassette; } \\
\text { - transgenic microrganism that } \\
\text { has this vector; and } \\
\text { - process to obtain a transgenic plant/ } \\
\text { transgenic plant cell. }\end{array}$ & $\begin{array}{l}\text { PI 1101063-0 } \\
\text { PI 1101069-0 } \\
\text { PI 1101067-3 } \\
\text { PI 1101045-2 } \\
\text { PI 1101070-3 }\end{array}$ & $\begin{array}{l}\text { October } 31^{\text {st }}, 2009 \\
\text { January } 17^{\text {th }}, 2003 \\
\text { January } 23^{\text {rd }}, 2007 \\
\text { January } 13^{\text {th }}, 2007 \\
\text { January } 17^{\text {th }}, 2003\end{array}$ \\
\hline II & $\begin{array}{l}\text { - recombinant expression cassette with } \\
\text { a specified mutated EPSPS }{ }^{1} \text { enzyme } \\
\text { sequence or GOX }{ }^{2} \text { enzyme sequence; } \\
\text { - vector that contains this } \\
\text { recombinant expression cassette; } \\
\text { - transgenic microrganism that } \\
\text { has this vector; and } \\
\text { - process to obtain a transgenic plant/ } \\
\text { transgenic plant cell. }\end{array}$ & $\begin{array}{l}\text { PI } 1100007-4 \\
\text { PI 1100008-2 } \\
\text { PI 1100006-6 }\end{array}$ & $\begin{array}{c}\text { August } 7^{\text {th }}, 2005 \\
\text { August } 31^{\text {st }}, 2010 \\
\text { June } 25^{\text {th }}, 2010\end{array}$ \\
\hline
\end{tabular}

The Article 230 establishes that the patent application whose matter is not patentable by the previous law, CPI 5.772/71 ${ }^{8}$, and whose corresponding patent was granted in the country of the origin may be granted a pipeline patent status if the matter does not conflict with Articles 10 and 18 of Law no. 9.279/96. This means that claims' pipelines must be regarded as an invention and be patentable according to the Brazilian Industrial Property Law (Law no. 9.279/96). However, the matter cannot be placed on any market by the direct initiative of

were filed through the Article 230 of the previously mentioned Law. The Article 229 applies the Law to all patent applications, except to one whose matter is not patentable by the previous law, CPI 5.772/71, and that is in accordance with Articles 230 and 231. The Article 231 allows a national or a person domiciled in Brazil to file a pipeline application whose matter is not patentable by the previous law, CPI 5.772/71. To do this, the matter cannot be placed on any market by the direct initiative of the owner or by third parties without his consent. Nor can third parties carry out serious and effective preparations for exploiting the matter of the application.

8 The CPI 5.772/71 did not consider patentable substances, matters or products obtained by chemical processes. Foodstuffs, chemicalpharmaceuticals of any type, as well as the respective process of obtaining or modifying them, were not patentable by CPI $5.772 / 71$ (Brasil 1971). the owner or by third parties with without his consent. Nor can third parties carry out serious and effective preparations for exploiting the matter of the application.

The extension of protection gave by a patent is determined by the content of the claims and is interpretated by specifications and drawings (Brasil 1996), when it is necessary. Thus, to have a better understanding of the protection rights conferred by the selected pipelines, this work deals with the issue of patent protection for inventions related to living organisms, as well as the implications and limits of this patent protection in the glyphosate tolerance soybean case.

\section{INTERFACE ANALYSis BETWEEN RR ${ }^{\circledR}$ SOYBEANS AND}

THEIR RELATED LEGISLATIONS: THE INDUSTRIAL PROPERTY LAW (LAW NO. 9.279/96) AND THE SCOPE of Protection of the Pipeline Pantents of GROUPS I AND II

In groups I and II, the patents' claims have at maximum two categories of invention, a product (or a physical object) and a process (or a method). The product and process claims intend to develop glyphosate 
tolerant soybeans, which can grow when glyphosate herbicide is applied to combat the weeds.

Concerning the product claims, some legal issues must be briefly explained. According to the Law no. 9.279/96, Brazil established that natural living beings, in the whole or in part, and biological material, including the genome or germ plasm of any natural living being, when found in nature or isolated, as well as natural biological processes, are not considered as an invention by the Article 10, section IX (Brasil 1996). It means that any genetic sequence of a plant, organ, tissue, cell plant or plant isolated from nature is not considered an invention, and, therefore, is not patentable. On the other hand, a DNA vector fusionated to a recombinant expression cassette, when it is not found in nature and is a product of human intervention, can be patent protected, in reference to topic 2.3 of the Guideline of Exam (INPI 2002). Therefore, the DNA vector with the recombinant expression cassete and the recombinant expression cassette per se of groups I and II can be considered an invention, new, and considering that it resulted from a human manipulation, thus being new and inventive, it can be patentable. According to the Article 18 , section III and sole paragraph, transgenic microorganisms that meet the three patentability requirements and are not mere discovery can be matter patentable, while living beings, in the whole or in part, cannot. Therefore, the transgenic plant and its parts (organs, tissues or cells), which are not considered by sole paragraph and section III of the Article 18 as transgenic microrganisms, are not patentable (Brasil 1996). However, the transgenic microrganism that has the vector claimed by either groups I or II is covered by the transgenic microrganism definition, and, for this reason, is patentable by the Article 18 (section III and sole paragraph). In relation the product claims, the Article $42^{9}$ of the Law no. 9.279/96 confers to the title's patent some exclusive rights over these product per se.

Regarding the method claims, there are two main types of them in the pipeline patents: the method to trans-

\footnotetext{
${ }^{9}$ According to Article 42: "A patent confers to its owner the right to prevent third parties from manufacturing, using, offering for sale, selling or importing for such purposes without his consent: I- a product that is the subject of a patent; II-a process or product directly obtained by a patented process;"
}

form a dicotyledonous to become tolerant to glyphosate and the method to transform a plant cell to become tolerant to glyphosate. Due to the fact that these process claims have, in their specification part, more than one step and are not natural biological processes, they can be considered an invention and, thus, they would be patentable if they were new and inventive. Although the Article 42 of the Law no. 9.279/96 also confers to the title's patent some exclusive rights over the process claim and the product obtained directly from this process, in this particular case, the products of these processes, the transgenic cells or the transgenic plants are not a patentable matter according to the transgenic microrganism definition of the Article 18 (section III and sole paragraph).

Summarizing, the scope of protection of the product claims - the DNA vector fusioned to a recombinant expression cassette, the recombinant expression cassette and the transgenic microorganisms - covers a protection to the owner of these pipeline patents of these products per se. The scope of protection of the process claims of these patentes - a process to obtain a glyphosate tolerant plant/plant cell by using a specific transgenic microrganism or a DNA vector with a specific expression cassette - reaches a patent protection only of the process per se.

INTERFACE ANALYSIS BETWEEN RR ${ }^{\circledR}$ SOYBEANS AND THEIR RELATED LEGISLATIONS: THE INDUSTRIAL

Property LAW (LAW NO. 9.279/96) AND THE

Exhaustion of Rights of the Matter Patentable IN the AgRicultural Biotechnology

Besides the Article 42 of the Law no. 9.279/96 confers to the title's patent the patent rights over a patented product and a patented process, this Article also determines the situations relative to the use, sale or importation of these matters. These situations define the exhaustion of rights of a patent. Then, the Article $42^{10}$ confers to the title's patent that its manufacturing, using, offering for sale, selling or importing must be done by the owner or with his consent. Another Article that enforces matters related to the exhaustion of rights is the

\footnotetext{
10 According to the Article 42: "A patent confers to its owner the right to prevent third parties from manufacturing, using, offering for sale, selling or importing for such purposes without his consent: I-a product that is the subject of a patent; II-a process or product directly obtained by a patented process;"
} 
Article 43. Especially in the sections V and VI, this Article states the exceptions of the Article 42 and the exhaustion of rights of the living matter patentable - the transgenic microrganism.

For a patent royalty discussion, beyond the definition of the scope of protection of the pipeline patents of groups I and II, it is important to analyze the moment of exhaustion of the rights of these selected patents. This work particularly focuses on the right of owners' patents to prevent third parties from manufacturing, using, offering for sale or selling, without their consent, the products and the processes that are matters of the patents selected. Considering Articles 42 and 43 of the Law no. 9.279/96, the patent exhaustion of rights of title's pipeline patents occurs when the title is rewarded by trading, offering for sale or selling (IDS 2005) these patented technologies - see Table I - to another enterprise to develop a glyphosate tolerant plant. For further details, see Figure 1 above.

Figure 1 illustrates a hypothetical model of the exhaustion of rights of the scope of the pipeline patents of groups I and II. The exhaustion of rights happens, in fact, at the moment that title X's patents are recompensed, which means during the trading of the matter of these pipeline patents with Enterprise Y. In this figure, it is clear that glyphosate tolerant soybeans and their seeds are not subject matters covered by the scope of these pipeline patents. On the other hand, these matters can be intellectually protected by a sui generis system - the Plant Variety Protection Law.

Internationally, recent discussions related to the exhaustion of rights of the scope of patents, which also protects glyphosate tolerance technologies, arrived in European Courts. Although the transgenic plant can be patent protected by the European Directive 98/44/EC (the European Parliament and the Council of the European Union 1998), the Brazilian Industrial Property Law does not apply for the plant patent protection. However, the conclusion of this Court case is worth considering in Brazillian Industrial Property Law. In Monsanto Technology LLC v. Cargill, the UK High Court's understanding of the scope of protection of the European patents is that the only patented product "directly obtained" from the patented process is the first genetically modified plant, then the subsequent generations of the plants and even the soya meal, which are not covered by this process claim (Cohen and Morgan 2008). Therefore, in this case, the scope of the European patents covers the recombinant DNA, the process to produce a genetically modified plant and its product. So, when Cargill imported soya meal from Argentina, it did not infringe on the European patents, once the exhaustion of rights of these patents had already occurred when the glyphosate tolerance technology was used to produce the genetically modified plant.

INTERFACE ANALysis BetweEn RR ${ }^{\circledR}$ SOYBEANS AND Related Legislations: the Plant Variety PROTECTION LAW (LAW NO. 9.456/97) AND THE INDUSTRIAL PROPERTY LAW (LAW NO. 9.279/96)

Although TRIPS agreement set up that Member States can protect plants by a sui generis system, by a patent law or by a combination of both, according to its Article 27.3(b), Brazil adopted the protection by just a sui generis system, the Plant Variety Protection Law. This law defines itself in its Article $2^{\text {nd }}$ as the only mechanism of variety protection and of rights that could oppose to the free use of plants and their reproduction or vegetative multiplication parts in Brazil. Thus, according to this Article, no other Law (including Industrial Property Law) enforces GM plants and their seeds. In order to show the differences between the Industrial Property Law protection and the Plant Variety Protection Law in a productive chain of a GM grain, a scheme was delineated (see Fig. 2).

While Brazil has only one legal system to protect plant varieties, the USA have three: the Utility Patent (since 1985), the Plant Protection Act (since 1930) and the Plant Variety Plant Act (since 1970). Each one protects a specific subject matter and has different protection requirements. The Utility Patent protects plant genotypes not normally found in nature. The Plant Protection Act protects assexually reproduced plants, including cultivated, mutants and hybrids, but excludes uncultivated and tuber propagated plants. The Plant Variety Protection Act protects sexually reproduced plants and excludes first generation hybrids and uncultivated plants (USA 1994, USPTO 2006).

In Europe, plant varieties and essentially biological processes for the production of plants are expressily 


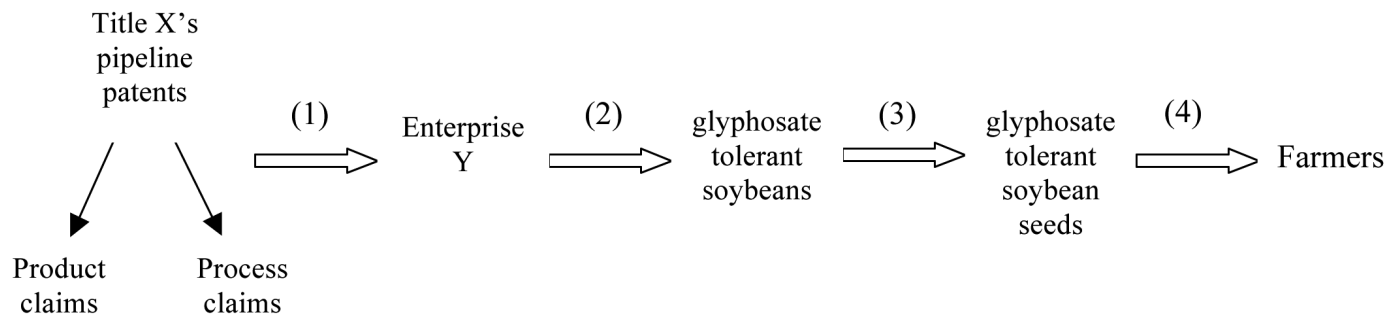

Fig. 1 - The scheme above demonstrates that the exhaustion of rights of title X's pipeline patents, which is determined by Law no. 9.279/96, occurs when they are rewarded by trading, offering for sale or selling (1) these patented technologies - product and process claims - to Enterprise Y. After this, Enterprise Y is legally able to use (2) the patented glyphosate tolerance technologies to develop glyphosate tolerant soybeans. These plants can be intellectually protected solely with the Plant Variety Protection Law (Law no. 9.456/97) by the Enterprise Y, which will produce (3) glyphosate tolerant soybean seeds in amounts to sell (4) them to the farmers.

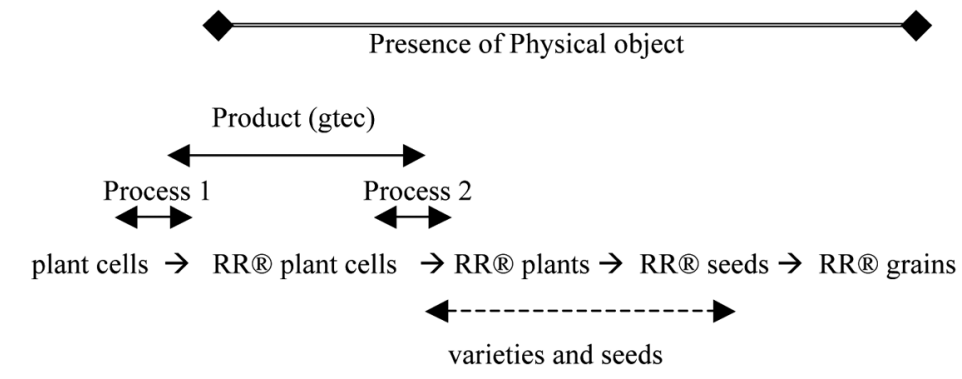

\section{- Industrial Property Law inventions \\ Plant Variety Protection Law inventions}

Fig. 2 - In the scheme above, the solid line corresponds to a subject matter regulated by the Industrial Property Law. The process claim 1 is the process to produce a genetically modified cell, and the process claim 2 is the process to produce a genetically modified plant. The product (physical object) refers to the glyphosate tolerance expression cassette (genetic product or gtec) inserted in the plant genome. Although this product is alongside of the grain chain (see double line), the exhaustion of rights of this product's claim occurred at the moment of its legal use to develop a genetically modified plant. The dotted line corresponds to the protection by the Plant Variety Protection Law, which protects the plant variety and the reproduction or vegetative multiplication parts of $\mathrm{RR}^{\circledR}$ seeds. The grains are seeds that are consumed and, therefore, they should not be legally considered as reproductive or multiplicative materials by the Plant Variety Protection Law.

forbidden of patent protection by Directive 98/44/EC. Otherwise, if an invention concerns plants, but the technical feasibility of this invention is not resricted to a particular plant variety, it could be patentable (the European Parliament and the Council of the European Union 1998). For example, transgenic plants produced by a process for production of plants by recombinant gene technology, once the plant varieties are not individually claimed, can be patentable ${ }^{11}$ (EPO 2010). However, if the invention is specifically a variety of some

\footnotetext{
${ }^{11}$ For further information, see case law G1/98 of European Patent Office Boards of Appeal.
}

botanical genera and species, including, inter alia, hybrids between genera and species, the protection will be covered by the Community Plant Variety Right - CPVR (the Council of the European Union 1994). The CPVR establishes a system for the protection of plant variety rights that is based on four Regulations (European Commission 2010). The following Table II summarizes the differences among the Brazilian, the US and the European legislations related to some agricultural biotechnology inventions.

Table II indicates that the only invention that is patent protected by Brazil, the US and European Union, 
TABLE II

Comparison of the intellectual property protection of some agricultural biotechnology inventions under the Brazillian, the US and the European legislations.

\begin{tabular}{c|c|c|c}
\hline \multirow{2}{*}{ Inventions } & Brazil & USA & European Union \\
\cline { 2 - 4 } & Legislation & Legislation & Legislation \\
\hline $\begin{array}{c}\text { process to obtain a } \\
\text { transgenic plant }\end{array}$ & $\begin{array}{c}\text { Industrial Property Law } \\
\text { (Law no. 9.279/96) }\end{array}$ & $\begin{array}{c}\text { Tilte 35 United State Code } \\
\text { (Utility Patent) }\end{array}$ & Directive 98/44/EC \\
\hline transgenic plants & $\begin{array}{c}\text { Plant Variety Protection Law } \\
\text { (Law no. 9.456/97) }\end{array}$ & $\begin{array}{c}\text { Tilte 35 United State Code } \\
\text { (Utility Patent) }\end{array}$ & Directive 98/44/EC \\
\hline $\begin{array}{c}\text { plant variety sexually } \\
\text { reproduced }\end{array}$ & $\begin{array}{c}\text { Plant Variety Protection Law } \\
\text { (Law no. 9.456/97) }\end{array}$ & $\begin{array}{c}\text { Title 7 United State Code } \\
\text { (Plant Variety } \\
\text { Protection Act) }\end{array}$ & $\begin{array}{c}\text { Community Plant Variety } \\
\text { Right - CVPR }\end{array}$ \\
\hline $\begin{array}{c}\text { plant variety } \\
\text { assexually reproduced }\end{array}$ & $\begin{array}{c}\text { Plant Variety Protection Law } \\
\text { (Law no. 9.456/97) }\end{array}$ & $\begin{array}{c}\text { Tilte 35 United State Code } \\
\text { (chapter 15 - } \\
\text { Plant Protection Act) }\end{array}$ & $\begin{array}{c}\text { Community Plant Variety } \\
\text { Right - CVPR }\end{array}$ \\
\hline
\end{tabular}

${ }^{1}$ Besides the Directive 98/44/EC, the European Union has also the European Patent Convention and Implementing Regulation to enforce patent protection. ${ }^{2}$ " 2 . Inventions that concern plants or animals shall be patentable if the technical feasibility of the invention is not confined to a particular plant or animal variety." (Article 4(2) of Directive 98/44/EC).

is the process to obtain a transgenic plant. Other inventions do not have equal protection among these countries. This table also reveals that Brazil is the only country that protects plants by a unique law, the others protect by industrial property laws or by plant variety laws. However, a legal comparison among developed and developing countries done by INPI (2007) showed that the Brazilian intellectual property protection pattern for the same inventions selected by Table II is identical to other developing countries' legislations, such as India and China.

\section{RR $^{\circledR}$ SOYEBEAn VARIETIES' Abstracts}

The analysis of the abstracts of the $\mathrm{RR}^{\circledR}$ soybean varieties granted and published in the Union Official Diary before May $27^{\text {th }}, 2008$, showed that all $R^{\circledR}$ soybean varieties $(\mathrm{n}=75)$ have in common, as a distinct information from the nearest varieties, the following term: "glyphosate herbicide tolerance".

The abstracts of 72 (from 75 varieties) do not reveal any information about the $\mathrm{RR}^{\circledR}$ genetic construction sequences that are inside these protected varieties or even the patent number that allows the protection of the $\mathrm{RR}^{\circledR}$ technologies that are inserted in these protected varieties. The three varieties from Fundação MT and Unisoja S/A (TMG 103RR ${ }^{\circledR}$, TMG 106RR ${ }^{\circledR}$ and TMG $108 \mathrm{RR}^{\circledR}$ ) were the only varieties that gave more detail to the meaning of the term "glyphosate tolerance". They reported the presence of a "CP4 EPSPS gene" in these soybeans as the distinctness that confers them the glyphosate resistance. Otherwise, these three varieties' abstracts do not reveal the sequence per $s e$ of the CP4 EPSPS gene or even the patent number for a more accurate indication of the sequence genes that are inside the genome of these varieties. Thus, when a farmer buys these varieties protected by the Plant Variety Protection Law (Law no. 9.456/97), he does not actually know which technologies are inside them. It is important to highlight this lack of information because the former sequence analysis with the BLAST and CLUSTAL Programs has just showed that each patent analyzed (PI 1100007-4 or PI 1100008-2) protects a different recombinant expression cassette that confers the same glyphosate tolerance.

\section{CONCLUSIONS}

In this work, the patents selected to protect the glyphosate tolerance technology were those protected by a transitory dispositive, which is also known as pipeline protection, and is represented by Articles 229, 230 and 231 of the Industrial Property Law (Law no. 9.279/96). In this work, it was possible to see that $\mathrm{RR}^{\circledR}$ technologies cover a set of pipeline patents that protects a 
physical object and a process to obtain plants using this physical object. In each patent, there are physical objects that cover: a vector, each one with a different genetic sequence that could be a glyphosate resistance one or not; a different genetic construction per se; and a transgenic microrganism. In addition, each patent also protects processes to produce a glyphosate tolerant genetically modified plant through this genetic construction or using this transgenic microrganism. However, transgenic plants and their parts that are originated by this process patented are not patentable by the Article 18 (section III and sole paragraph) of the Law no. 9.279/ 96. Since $R^{\circledR}{ }^{\circledR}$ technologies cover different patents, it is important to consider that, besides the scope of protection of each patent, for each one there is a different term (or period) of protection that limits temporally the right of the title of the patents. In addition to this, the Article 42 of the Law no. 9.279/96 establishes that the title of inventions - the set of glyphosate tolerance technology patents - during the commercial selling of these patents, are rewarded, and, after this, their rights are exhausted.

The analysis of the pipeline's claims revealed the different matters that are covered by their scope of protection of each pipeline patent. In addition, patents that revealed protein sequences have distinct sequences that confer the characteristic of glyphosate resistance, as showed by the BLAST and CLUSTAL tools. In this way, these results showed clearly that the boundaries of the patent protection are different, as well as the terms of protection of each patent. Therefore, these results point out to the fact that, in each agreement that envolves technology transfer to develop a new plant variety, between the title of patent and an enterprise, for example, the agreement must have the patent number in order to specifically define the subject matter that has been negotiated and the term of protection of the patent that supports the agreement. Once the Industrial Property Law allows different inventions to be patented through different patents and the title of invention to explore it for a specific period, then when the patents expire, third parties may explore these inventions and also get in to the market.

Glyphosate tolerant plants and their reproductive (or multiplication) parts, such as their seeds, are protected by one legal apparatus, the Plant Variety Protec- tion Law (Law no. 9.456/97). Once glyphosate tolerant grain obtained by a legal seed had already had its intellectual property rights exhausted at the moment of selling legal seeds, therefore, at this time, it is not possible to apply any other intellectual property rights based on the Industrial Property Law. The protection over the subject matter involving plants and their reproductive or multiplicative parts is granted only by Law no. $9.456 / 97$. So, the breeders must authorize the legal trade of the glyphosate resistant plant varieties and their reproductive or multiplicative parts. This observation highlights the fact that the variety protection has a term of protection and a moment when the breeder's rights are exhausted, which are different from the patents of invention. So, because of these different terms of protection, the chargement for the variety protection and for the patents of invention protection has to be in agreement with these differences.

The analysis of all published abstracts of $R^{\circledR}$ soybean varieties showed that none of them mentioned the glyphosate resistance genetic construction sequence that is inside the variety protected, nor the patent number that protects the glyphosate resistance technology. In this way, it is not possible to establish a relationship between the invention protected by Industrial Property Law and the variety that is protected by the Plant Variety Protection Law. Therefore, whoever buys an intellectual protected glyphosate tolerant seed, in fact, buys a "black box" in relation to its patent information. In order to solve this problem, the public abstracts of the Plant Variety Protection must consider the patent number of the glyphosate resistant technology as an information of the distinctness requirement or at least the DNA construction sequence per se that confers the variety the glyphosate tolerance. So, if one of the distinctness requirements is the glyphosate resistant sequence, thus this information must be in the public abstracts of the plant variety protection.

The value aggregation to the soy seeds through the technology apropriated by the Industrial Property Law and by the Plant Variety Protection Law has been increasing, and probably will continue in the next years.

It is important to keep in mind the fact that agricultural business represents, nowadays, 39\% of the Brazilian exportation, $34 \%$ of the Gross Domestic 
Product (GDP) and 37\% of the work force. According to Rodrigues (2005), the agricultural field is a sector in expansion that is able to participate more in the world trade. In this context, if the Brazilian society desires to be benefited with a robust intellectual property protection, as Plant Variety Protection Law tends to be, the national innovation politics - like Politics of Development of Biotechnology (Brasil 2007) - must be effective in decreasing the technological dependence and improving the national industry competitive capacitation, especially in high intensity technology sectors, such as agricultural biotechnology.

\section{ACKNOWLEDGMENTS}

Many thanks are due to several people from Brazil and the institutions they represent: Msc. Bianca Castro (Universidade Federal Rural do Rio de Janeiro - UFRRJ), Daniela de Moraes Aviani and Heloísa Carvalho (Serviço Nacional de Proteção de Cultivar - SNPC), José Américo Rodrigues and Msc. Paulo Campante (Associação Brasileira de Sementes e Mudas - ABRASEM), Msc. Luciana Harumi Morimoto Figueiredo (Empresa Brasileira de Pesquisa Agropecuária/Distrito Federal - EMBRAPA-DF), Msc. Claudete Teixeira Moreira (EMBRAPA-DF), Lia Medeiros (Diretoria de Transferência de Tecnologia / Instituto Nacional da Propriedade Industrial - DIRTEC/INPI), Thiago Carneiro (Divisão de Biotecnologia / Instituto Nacional da Propriedade Industrial - DIBIOTEC/INPI), Msc. Luís Cláudio Martins de Moura (Universidade Federal de Goiás - UFG), Dr. Joel Orlando Bevilaqua Marin (UFG) and Rachel Loerch Japiassu.

\section{RESUMO}

O presente trabalho analisa as diferentes modalidades de proteção das criações intelectuais no campo da biotecnologia agrícola. A partir das leis Brasileiras relacionadas ao tema (Lei da Propriedade Industrial - n 9.279/96 e Lei da Proteção de Cultivares $\left.-\mathrm{n}^{\circ} 9.456 / 97\right)$, e com base nos tratados internacionais assinados pelo Brasil, o presente trabalho aponta as inclusões de cada uma, assim como, suas interfaces usando como referência o estudo de caso da soja geneticamente modificada para tolerância ao glifosato. Para este caso, patentes pipelines da Monsanto foram buscadas e usadas para analisar os limites de proteção das patentes frente às outras leis de Propriedade Intelectual (PI) relacionadas. Assim, foi possível elucidar o cenário complexo da Propriedade Intelectual das sojas tolerantes ao glifosato, já que para o agricultor não é fácil correlacionar o pagamento dos royalties com os direitos de PI da empresa

Palavras-chave: biotecnologia, OGM, propriedade intelectual, patente, pipeline, soja.

\section{REFERENCES}

ANÁLISE. 2007. São Paulo: Análise, p. 183-184.

Brasil. 1971. Código da Propriedade Industrial $n^{\circ} 5.772$, de 21 de dezembro de 1971. Institui o novo Código da Propriedade Industrial, e dá outras providências.

BRASIL. 1996. Lei de Propriedade Industrial, $\mathrm{n}^{\circ} 9.279,14$ de maio de 1996. Brasília-DF.

Brasil. 1997. Lei de Proteção de Cultivares, $n^{\circ}$ 9.476, 25 de abril de 1997. Brasília-DF.

BRASIL. 2007. Decreto $n^{\circ}$ 6.041, 8 de fevereiro de 2007. Brasília-DF.

Cohen S And Morgan G. 2008. Monsanto Technology LLC v. Cargill: a matter of construction. Nat Biotech 26: 289-291.

de Carvalho SP, Salles Filho SlM and Buainaim AM. 2005. A inconstitucionalidade da propriedade intelectual no Brasil: os impactos da política de articulação da Embrapa no mercado de cultivares no Brasil. Cad de Est Avan, p. 35-46.

EPO. 2010. Case Law of the boards of appeal of European Patent Office. Available at: <http://legal.european-patentoffice.org/dg3/biblio/G980001ep1.htm>. Accessed on: Jul., 2010.

European Commission. 2010. Food Safety - From the farm to the fork. Plant Variety Property Rights. Available at: <http://ec.europa.eu/food/plant/propertyrights/index_en.htm>. Accessed on: Jul. 2010.

IDS. 2005. Comentários à Lei da Propriedade Industrial edição revista e atualizada - Rio de Janeiro: Renovar, p. $79-105$.

INPI. 2001. Centro de Documentação e Informação Tecnológica. 2001. Nota sobre Patente e Biotecnologia.

INPI. 2002. Diretrizes para o exame de pedidos de patentes nas áreas de biotecnologia e farmacêutica depositados após 31/12/1994. Published by RPI no. 1648, August, $6^{\text {th }}, 2002$.

INPI. 2007. Diretoria de Articulação. Centro de Documentação e Informação Tecnológica. Divisão de Estudos e 
Programas. Elaborated by Grupo de Trabalho Especial em Biotecnologia. Estudo Comparativo dos Critérios de Patenteabilidade para Invenções Biotecnológicas em Diferentes Países.

JAMES C. 2005. Global status of commercialized transgenic crops: 2005, ISAAA Brief 34, International Service for the Acquisition of Agri-biotech Applications, Ithaca, $58 \mathrm{p}$.

LAWRENCE S. 2008. Brazil surpasses US in new transgenic crop plantings. Nat Biotech 26(3): 260.

Ministério DA Agricultura. 2008a. Agronegócio Brasileiro: uma oportunidade de investimentos. Available at: $<$ www.agricultura.gov.br>. Acessed on: Oct., 2008.

Ministério dA Agricultura. 2008b. O que é Zoneamento Agrícola de Risco Climático? Available at:

$<\mathrm{http}: / /$ www.agricultura.gov.br/portal/page?_pageid=33,1007023

\&_dad=portal\&_schema=PORTAL $>$. Accessed on: Nov., 2008.

OECD/EUROSTAT. 1997. OECD Proposed guidelines for collecting and interpreting technological innovation data - Oslo Manual, Third edition. OECD, Paris.

Pessanha L, Wilkinson J, de Castro BS and MoRENO C. 2006. Socio-economic and Political Impacts of the extension of transgenic soy production on farmers in South America. In: ANAIS VII. CONGRESSO LATINOAmericano De Sociologia Rural, Quito, Peru, p. 1-20.

QUAIM M AND TRAXLER G. 2005. Roundup ready soybeans in Argentina: farm level and aggregate welfare effects. Agri Econ 32: 73-86.

Rodrigues R. 2005. Mapa moderniza estrutura interna para apoiar crescimento do agronegócio. Rev de Política Agrícola 1: 3-6. Available at: <http://www.agronegocioe.com.br/agronegocio/artigos.agr $>$. Accessed on: jul., 2008.

Santos Filho O And Alencastro RB De. 2003. Modelagem de proteínas por homologia. Quim Nova 26(2): 253-259.
The Council of the European Union. 1994. Council Regulation 9EC) No. 2100/94 of 27 July 1994 on Community plant variety rights. Available at: $<$ http://eurlex.europa.eu/LexUriServ/LexUriServ.do? uri=CONSLEG:1994R2100:20080131: EN:PDF>. Accessed on: Jul. 2010.

The European Parliament and The Council of the European Union. 1998. Directive 98/44/EC of the European Parliament and of the Council of 6 July 1998 on the legal protection of biotechnological inventions.

TRIPS - AGREEMENT ON TRADE-RELATED AsPECTS OF Intellectual Property Rights. 1994. Marrakesh Agreement Establishing the world Trade Organization (Apr. 15 th 1994$)$, Annex 1C.

USA. 1994. Plant Variety Protection Act (Public Law 91.577), approved on Dec. $24^{\text {th }}, 1970$.

USPTO - United State Patent And Trademark OfFICE. 2006. Manual of Patent Examinig Procedure. Original $8^{\text {th }}$ ed., Aug. 2001/ Latest Revision on Aug., 2006. US Departament of Commerce/ United States Patent and Trademark.

VARela L And Bisang R. 2006. Biotechnology in Agriculture faces world-wide concentration. J Biotech 9(3): 227-231.

Vasconcellos AG, Esquibel MA and Lage ClS. 2005. Proteção patentária de fitoterápicos no Brasil: um estudo sobre os depósitos de patentes ao longo da década de 90. Rev Bras de Plantas Med 7(1): 51-56.

WTO - WORLD TRAdE ORganization. 2008. Overview: the TRIPS agreement. Available at: $<$ www.wto.org/english/tratop_e/trips_e/intel2_e.htm $>$. Accessed on: August, 2008. 